\title{
STUDY OF A COMBINED METHOD (DRYING AND FRYING) TOASTED TORTILLA MANUFACTURING
}

\author{
Morales-Pérez J., Sosa-Morales M.E. and Vélez-Ruiz J.F. \\ Chemical and Food Engineering Department, Universidad de las Américas, Puebla. \\ Sta. Catarina Mártir, Cholula, 72820 Puebla., México \\ jorgef.velez@udlap.mx
}

\begin{abstract}
The purpose of this study was to combine advantages of two processes: air drying and frying to produce toasted tortillas with lower fat content in comparison with those commercial items existing in the market. Product characterization of four commercial brands was carried out; characteristics, such as moisture (1.8-6.7\%) and fat percentages (22-28\%), color parameters (L: 23-25, a: 0.04-0.18, b: 1.3-2.5) and texture (5.8-7.6 N) were measured in order to establish a reference frame. Drying with hot air $\left(35,48\right.$ and $\left.68^{\circ} \mathrm{C}\right)$ at 2,4 and $6 \mathrm{~m} / \mathrm{s}$ were applied to dry tortillas, in which the final moisture contents were in the range of $6-12 \%$ and taking $30-200$ min of treatment, as a function of the variables, to reach $10 \%$ of moisture. While frying was conducted with a standardized initial moisture of $10 \%$ at 140,160 and $180^{\circ} \mathrm{C}$, in which only two minutes were utilized to get the toasted tortillas. In general terms, at a given temperature lower moisture and higher fat contents were measured for longer frying times, and finding that tortillas dried at $4 \mathrm{~m} / \mathrm{s}$ resulted in better product attributes. There was significant effect of the drying conditions on the fried product. The toasted product had 2-4\% moisture, $10-12 \%$ fat, which is lower than commercial products; and it developed similar quality attributes to those of commercial "tostadas". Mass transfer parameters were computed for processes, drying and frying. Finally an optimization was carried out, with the Design Expert software and experimentally as well.

Key words: toasted tortillas, frying, drying,
\end{abstract}

\section{INTRODUCTION}

The world market for snack foods is continuously growing and represents huge quantities of money; one important snack in Mexico is the toasted tortilla, either in small pieces (chips) or complete tortilla pieces ("tostadas"). This food product includes a frying treatment as part of the manufacturing process, in which oil is incorporated to the product. On the other side, consumer preferences for low and free fat food items is a present driven force to produce them in the food industry. Even tough, some papers on chips processing and characterization have been published (Moreira et al., 1995; 1997), there is few information on tostadas and less information exits on the combination of air drying and frying to manufacture toasted tortillas with low fat content.

\section{RESULTS AND DISCUSSION}

Drying: During the drying runs of tortilla the next times of process were recorded to reach a $10 \%$ of moisture content (Table1), starting with an initial moisture of $40-42 \%$. As expected, lower times corresponded to higher temperatures and times, nevertheless at 48 and $68^{\circ} \mathrm{C}$ a contrary trend was observed for 4 and $6 \mathrm{~m} / \mathrm{s}$, requiring a lower drying time at $4 \mathrm{~m} / \mathrm{s}$ than at 6 $\mathrm{m} / \mathrm{s}$ to get the same moisture. Most likely a case hardening phenomena was present in tortilla at $6 \mathrm{~m} / \mathrm{s}$, avoiding higher water evaporation. Moisture and fat content, as well as texture were significantly $(\alpha=0.05)$ affected by the drying temperature, whereas the net color difference $(\Delta \mathrm{E})$ was not affected.

Frying: For the deep-frying process a dried tortilla with $10 \%$ moisture was employed to produce the so named tostadas or toasted tortillas. The main data obtained from this part of 
the research for tostadas manufacturing are included in Table 2. Water content and texture were significantly $(\alpha=0.05)$ affected by the frying temperature, whereas the fat content and net color difference $(\Delta \mathrm{E})$ did not show effect of temperature.

Table 1. Drying times of tortilla

\begin{tabular}{|c|c|c|}
\hline $\begin{array}{c}\mathrm{T} \\
\left({ }^{\circ} \mathrm{C}\right)\end{array}$ & $\begin{array}{l}\text { air velocity } \\
\qquad(\mathrm{m} / \mathrm{s})\end{array}$ & $\begin{array}{l}\text { time } \\
(\mathrm{min})\end{array}$ \\
\hline 35 & $2,4,6$ & $172,174,200$ \\
\hline 48 & $2,4,6$ & $95, \quad 42, \quad 71$ \\
\hline 68 & $2,4,6$ & $30, \quad 45, \quad 55$ \\
\hline
\end{tabular}

Table 2. Properties of toasted tortillas

\begin{tabular}{|c|c|c|c|c|}
\hline $\begin{array}{c}\mathrm{T} \\
\left({ }^{\circ} \mathrm{C}\right)\end{array}$ & $\begin{array}{c}\text { Water } \\
(\%)\end{array}$ & $\begin{array}{l}\text { Fat } \\
(\%)\end{array}$ & $\Delta \mathrm{E}$ & $\begin{array}{l}\text { Texture force } \\
\text { (N) }\end{array}$ \\
\hline 140 & $4-8$ & $8-1$ & $8-12$ & $6.6-12.3$ \\
\hline 160 & $2-4$ & $9-17$ & $6-14$ & $4.2-12.9$ \\
\hline 180 & $1-3$ & $10-17$ & $9-17$ & $6.0-14.1$ \\
\hline
\end{tabular}

Modeling: The mass transfer of both processes was followed, finding a constant drying period of 40 minutes at the three temperatures for the highest air velocity, and also for $4 \mathrm{~m} / \mathrm{s}$ at 48 and $68^{\circ} \mathrm{C}$. And for $35^{\circ} \mathrm{C}$ and $48^{\circ} \mathrm{C}$ at the lowest air velocity, the constant drying time increased up to 80 minutes. Moisture loss ranged from 0.10 to $1.3 \times 10^{-2} \mathrm{~kg}$ water $/ \mathrm{min}$ during the drying operation, being noticeably higher than those obtained for the frying process $(0.03$ to $0.24 \times 10^{-2} \mathrm{~kg}$ water $/ \mathrm{min}$ ). An inverse relationship was observed among operations, that is to say, faster water evaporation during drying generated slower moisture loss during frying.

For the unstable mass transfer period, in which the solution to the second Fick's law was used, a contrary pattern was shown, lower diffusional coefficients (D) were computed for drying (4-9 x $\left.10^{-11} \mathrm{~m}^{2} / \mathrm{s}\right)$ than for frying $\left(1.8-4.410^{-9} \mathrm{~m}^{2} / \mathrm{s}\right)$. The calculated $\mathrm{D}$ for the drying operation is in agreement with those reported by Moreira et al. (1995) and Sosa et al. (2006)

Optimization: From the response surface (Design Expert) following the Box Behnken model, a set of experimental conditions was obtained from the software. Then those variables were controlled and an experimental run was carried out for tostadas manufacturing, and from the results the next equations were generated, being $\mathrm{A}$ the air temperature $\left(35-68^{\circ} \mathrm{C}\right)$; $\mathrm{B}$ the air velocity $(2-6 \mathrm{~m} / \mathrm{s}) ; \mathrm{C}$ the frying temperature $\left(140-180^{\circ} \mathrm{C}\right)$, and $\mathrm{D}$ the frying time $(30-120 \mathrm{~s})$.

$$
\begin{aligned}
& \text { Moisture }(\%)=4.78-0.63 \mathrm{~A}+0.78 \mathrm{~B}-0.74 \mathrm{C}-0.87 \mathrm{D}+1.35 \mathrm{~A}^{2}-0.033 \mathrm{~B}^{2}+0.65 \mathrm{C}^{2} \\
& +4.561 \mathrm{AB}+0.03 \mathrm{AC}+0.092 \mathrm{AD}+0.25 \mathrm{BC}+0.20 \mathrm{BD}-0.12 \mathrm{CD} \\
& \text { Fat }(\%)=14.42+1.3 \mathrm{~A}-0.96 \mathrm{~B}+1.12 \mathrm{C}-0.36 \mathrm{D}+0.25 \mathrm{~A}^{2}-2.90 \mathrm{~B}^{2}-2.17 \mathrm{C}^{2}-0.77 \mathrm{AB} \\
& +1.18 \mathrm{AC}+1.10 \mathrm{AD}-0.67 \mathrm{BC}+1.03 \mathrm{BD}+0.033 \mathrm{CD} \\
& \text { Ruptureforce }(\mathrm{N}) .=10.80-2.68 \mathrm{~A}+0.32 \mathrm{~B}+2.18 \mathrm{C}-1.56 \mathrm{D}+0.82 \mathrm{AB}-4.52 \mathrm{AC}+3.15 \mathrm{AD} \\
& -0.33 \mathrm{BC}-0.13 \mathrm{BD}+0.53 \mathrm{CD} \\
& \Delta \mathrm{E}=36.79-1.94 \mathrm{~A}+4.24 \mathrm{~B}+3.08 \mathrm{C}+5.60 \mathrm{D}
\end{aligned}
$$

\section{REFERENCES}

Moreira R.G., Palau J.E. and Sun X. 1995. Deep-fat frying of tortilla chips: an engineering approach. Food Technology. 4: 146.

Moreira, R.G., Sun X. and Chen Y. 1997. Factors affecting oil uptake in tortilla chips in deepfat frying. Journal of Food Engineering. 31: 485.

Sosa-Morales, M.E., Orzuna-Espíritu R. and Vélez-Ruiz J.F. 2006. Mass, thermal and quality aspects of deep fat frying of pork meat. Journal of Food Engineering. 77(3): 731. 